\title{
Ultrasound in schistosomiasis mansoni
}

\section{Rogério Augusto Pinto-Silva ${ }^{1 /+}$, Leonardo Campos de Queiroz ${ }^{1,2}$, Letícia Martins Azeredo', Luciana Cristina dos Santos Silva ${ }^{2}$, José Roberto Lambertucci ${ }^{1,2}$}

${ }^{1}$ Serviço de Radiologia, Hospital das Clínicas 2Programa de Pós-Graduação em Ciências da Saúde: Infectologia e Medicina Tropical, Faculdade de Medicina, Universidade Federal de Minas Gerais, Belo Horizonte, MG, Brasil

We reviewed ultrasound features in patients with schistosomiasis mansoni. The alterations that we observed in acute and hepatosplenic schistosomiasis are described. The advantages and disadvantages of using ultrasound patterns in the evaluation of liver fibrosis are discussed. Other diseases that are important in the differential diagnosis of schistosomal liver fibrosis are presented. Ultrasound is an effective and flexible diagnostic tool in the evaluation of a variety of diseases. It presents no harmful effects to patients, allowing non-invasive studies in hospitalized patients and in other facilities.

Key words: ultrasonography - ultrasound - schistosomiasis - diagnostic imaging - hepatosplenic schistosomiasis

Abdel Wahab et al. (1979) were the first to report the ultrasound features of hepatosplenic schistosomiasis mansoni. Their findings were confirmed by several investigators in Africa (Fataar et al. 1984, Hussain et al. 1984) and in Brazil (Cerri et al. 1984, Domingues et al. 1993, Pinto-Silva et al. 1994, Lambertucci et al. 2001, 2008).

Table I summarises the main findings reported by the above investigators. The first studies were carried out in hospitalized patients with severe hepatosplenic schistosomiasis; in most cases, there was also a history of upper digestive bleeding. In this scenario, ultrasound proved to be efficient in the diagnosis of liver fibrosis and in the differential diagnosis with other chronic liver diseases such as cirrhosis, steatosis and liver abscesses. In addition, ultrasound facilitated the exclusion of other diseases that evolved with splenomegaly, such as kalazar, lymphoma and portal vein thrombosis (Homeida et al. 1988).

Liver fibrosis findings in ultrasound are similar to those described by pathologists in the autopsy theatre (Bogliolo 1957, Andrade \& Bina 1983, Lambertucci et al. 2000). The schistosomal periportal fibrosis appears like an echogenic band surrounding the portal vessels from the hilum to the periphery of the liver; in advanced cases, the liver surface may develop pseudonodules as a result of fibrous tissue scaring and retraction. The gallbladder wall is thickened by echogenic tissue as shown in Fig. 1. Liver parenchymal echogenicity is usually preserved. The portal vein and its tributaries are generally dilated. Collateral veins with hepatofugal flow are frequently reported, especially in the following veins: left gastric, short gastric, splenorenal and parumbilical. In the parumbilical vein, the blood flows toward the um-

+ Corresponding author: rapsilva@gmail.com

Received 19 May 2009

Accepted 15 October 2009 bilical scar, where it joins the superficial epigastric veins and may originate the "caput medusae".

With the intense use of ultrasound in everyday life, the authors noticed that other diseases shared some characteristics of the schistosomal hepatopathy. For example, other diseases presented some degree of periportal thickening in the hilum, like chronic portal thrombosis (cavernomatous transformation of the portal vein). Another difficulty comes from the coexistence of chronic hepatic viral infection or liver cirrhosis, which turn out to be difficult to differentiate from the hepatosplenic form of schistosomiasis. Table II lists the differential diagnoses of Symmers fibrosis and depicts some clues for differentiating them.

Documented ultrasonographic regression of liver fibrosis was reported by Homeida et al. (1991) in 28 patients three years after treatment with praziquantel. Cota et al. (2006) studied 84 patients from a rural endemic area of Brazil four years after treatment with oxamniquine and confirmed the regression of fibrosis in $32 \%$ of the patients and the disappearance of splenomegaly in $48 \%$ of the patients.

Ultrasound showed moderate inter-observer reproducibility (kappa $=0.46$ ) for patterns $\mathrm{C}$ through $\mathrm{F}$ of the Niamey-Belo Horizonte Protocol and a perfect intraobserver reproducibility (1.00) for static images. In addition, an agreement of 0.43-0.57 was observed for the dynamic study of the same patient in different moments; this was considered satisfactory compared to mammography readings using the Breast Imaging Reporting and Data System criteria of the American College of Radiology. For mammography, the agreement ranges from 0.25-0.75 (Santos et al. 2007).

Ultrasound and doppler imaging in schistosomal portal hypertension - Portal hypertension can be suspected by B-mode sonography when dilation of one or more of the portal, mesenteric and splenic veins is observed (typical diameters for adults are: portal vein, $\leq 12 \mathrm{~mm}$; superior mesenteric and splenic veins, $\leq 9 \mathrm{~mm}$ ) and when the collateral veins are present. The most commonly described collateral veins are the left and right gastric, the short gas- 

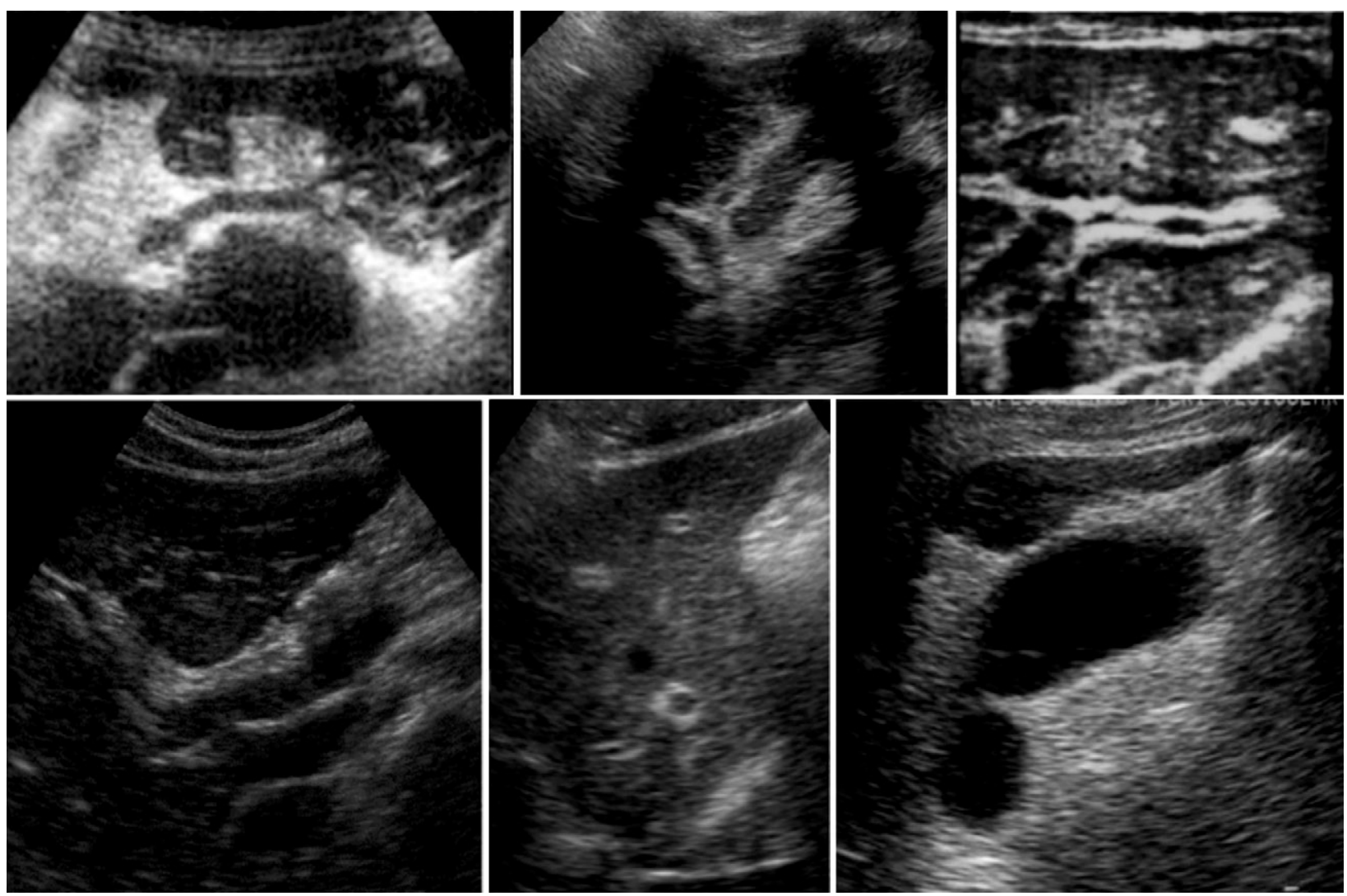

Fig. 1: periportal and gallbladder echogenic thickening in hepatosplenic schistosomiasis mansoni.

TABLE I

Ultrasound findings in Symmers' fibrosis

\section{Periportal thickening}

Echogenic thickening of the gallbladder wall

Liver right lobe reduction

Liver left lobe augmentation

Splenomegaly

Portal tract vessels dilation

Hepatofugal collateral circulation

Portal thrombosis $(5-10 \%$ of cases)

tric, the parumbilical and the splenorenal. Other vessels are less frequently observed, especially splenointercostal veins and direct shunting between portal branches and hepatic veins (Pinto-Silva et al. 1994).

Colour Doppler increases the sensitivity of ultrasound because it detects the presence and direction of blood flow and the presence of hepatofugal circulation. Moreover, it is possible to measure flow velocity and to estimate the flow volume-per-minute, which indirectly assesses any physiopathological changes in portal circulation.

Vezozzo et al. (2006) did not find significant differences in the Doppler findings between patients with hepatosplenic and hepatointestinal schistosomiasis. A dilated parumbilical vein can increase portal flow velocity and volume-per-minute (Widman et al. 2001). The absence of blood flow indicates acute thrombosis or a very slow flow (Vezozzo et al. 2006). Portal thrombosis is more frequently observed after portal hypertension surgery (de Cleva et al. 2005).

The hepatic veins in schistosomiasis remain patent with normal phasic flow as the disease evolves, which is different from liver cirrhosis. In advanced cirrhosis, hepatic venous outflow becomes monophasic. The right hepatic vein is closer to the diaphragm as a result of atrophy of the posterolateral segment of the right liver lobe. There is no consensus about the presence of alterations in the hepatic artery flow in hepatosplenic schistosomiasis. Most authors have found no variations (Bogliolo 1957, Coutinho 1964), whereas some observed a compensatory increase in arterial blood flow (Andrade \& Cheever 1971). The splenic artery is dilated with increased blood flow in patients with massive splenomegaly.

Ultrasound in acute schistosomiasis mansoni - Lambertucci et al. (1994) and Rabello et al. (1994) described the sonographic features of acute schistosomiasis in both adults and children. The findings included hepatic and splenic enlargement without focal parenchymal lesions and increased periportal and mesenteric lymph nodes. The echogenic hilum of lymph nodes was enlarged and 
TABLE II

Differential diagnosis of schistosomal hepatic fibrosis by ultrasound

\begin{tabular}{|c|c|c|c|}
\hline Diseases & $\begin{array}{l}\text { May simulate } \\
\text { WHO patterns }\end{array}$ & $\begin{array}{l}\text { Findings shared } \\
\text { by the diseases }\end{array}$ & Clues to differential diagnosis \\
\hline Congenital liver fibrosis & $\mathrm{C}$ or $\mathrm{D}$ & $\begin{array}{l}\text { Periportal thickening } \\
\text { Pre-sinusoidal } \\
\text { portal hypertension } \\
\text { Normal liver function }\end{array}$ & $\begin{array}{l}\text { Occur in small children } \\
\text { Associated with cystic renal disease }\end{array}$ \\
\hline $\begin{array}{l}\text { Biliary hamartomas } \\
\text { (von Meyenburg complex) }\end{array}$ & $\mathrm{B}$ & $\begin{array}{l}\text { Multiple echogenic foci } \\
\text { resembling granulomas }\end{array}$ & $\begin{array}{l}\text { Periportal and gallbladder wall thickening are absent, } \\
\text { as well as portal hypertension and splenomegaly }\end{array}$ \\
\hline $\begin{array}{l}\text { Hepatic glycogen } \\
\text { depletion }\end{array}$ & $\mathrm{C}$ & Diffuse periportal thickening & $\begin{array}{c}\text { Hypoechogenic liver } \\
\text { (less echogenic than kidney and spleen) } \\
\text { More common in children and } \\
\text { thin adults fasting for long periods } \\
\text { Gallbladder wall thickening absent, as well } \\
\text { as portal hypertension and splenomegaly }\end{array}$ \\
\hline $\begin{array}{l}\text { Primary sclerosing } \\
\text { cholangitis }\end{array}$ & $\mathrm{C}$ & $\begin{array}{l}\text { Mild irregular periportal } \\
\text { thickening } \\
\text { Splenomegaly }\end{array}$ & $\begin{array}{l}\text { Periportal lymph node enlargement } \\
\text { Normal gallbladder wall or mildly } \\
\text { and smoothly thickened }\end{array}$ \\
\hline Auto-immune hepatitis & $\mathrm{D}$ & $\begin{array}{l}\text { Hilar periportal thickening } \\
\text { Portal hypertension } \\
\text { Splenomegaly }\end{array}$ & $\begin{array}{l}\text { Diffuse heterogeneity of liver parenchyma } \\
\text { Typical patient: young woman } \\
\text { Liver enzymes altered } \\
\text { History of auto-immune disease } \\
\text { Normal gallbladder wall or mildly } \\
\text { and smoothly thickened }\end{array}$ \\
\hline $\begin{array}{l}\text { Congenital or acquired } \\
\text { chronic portal thrombosis }\end{array}$ & $\mathrm{F}$ & $\begin{array}{l}\text { Hilar periportal thickening } \\
\text { Portal hypertension } \\
\text { Splenomegaly }\end{array}$ & $\begin{array}{c}\text { Portal vein not seen (use of colour Doppler is advised) } \\
\text { Periportal tortuous collateral circulation } \\
\text { Peripheral periportal thickening absent } \\
\text { Normal gallbladder wall or mildly } \\
\text { and smoothly thickened }\end{array}$ \\
\hline Cirrhosis & $\mathrm{C}$ or $\mathrm{D}$ & $\begin{array}{l}\text { Mild periportal thickening } \\
\text { Irregular hepatic surface } \\
\text { Portal hypertension } \\
\text { Splenomegaly }\end{array}$ & $\begin{array}{c}\text { Diffuse heterogeneity of liver parenchyma } \\
\text { Normal gallbladder wall or mildly } \\
\text { and smoothly thickened } \\
\text { Liver enzymes altered }\end{array}$ \\
\hline
\end{tabular}

was surrounded by a thin symmetric hypoechoic cortex. This finding is not specific for acute schistosomiasis, being observed in other hepatobiliary inflammatory diseases. The sonographic features of acute schistosomiasis are shown in Fig. 2.

Acute schistosomal granulomas are not usually detected by ultrasound. Other imaging methods such as computed tomography (Cesmeli et al. 1997) and magnetic resonance imaging (MRI) may show them after contrast injection as non-enhancing nodules. Ultrasound Doppler shows hepatic artery hyperaemia, probably because of acute inflammatory changes (Barata et al. 1999).

Field studies - mass treatment response evaluation World Health Organization (WHO) protocol - Many fieldbased studies have been performed in African and South
American countries to establish ultrasound characteristics and reproducibility (Lambertucci et al. 1987). Homeida et al. (1988) conducted the first study in Sudan, with periportal fibrosis being reported in $19.8 \%$ of the 297 patients examined. Comparing three different populations, the investigators found that the prevalence of fibrosis was higher among those not treated for schistosomiasis. Periportal thickening suggestive of fibrosis was found more frequently than hepatosplenomegaly by clinical examination.

Doehring-Schwerdtfeger et al. (1989) evaluated 536 Sudanese children with Schistosoma mansoni infection and reported predominant central periportal fibrosis on ultrasound. On the other hand, Homeida et al. (1988) described periportal thickening that started in the peripheral branches and progressed towards the hilum as the disease 

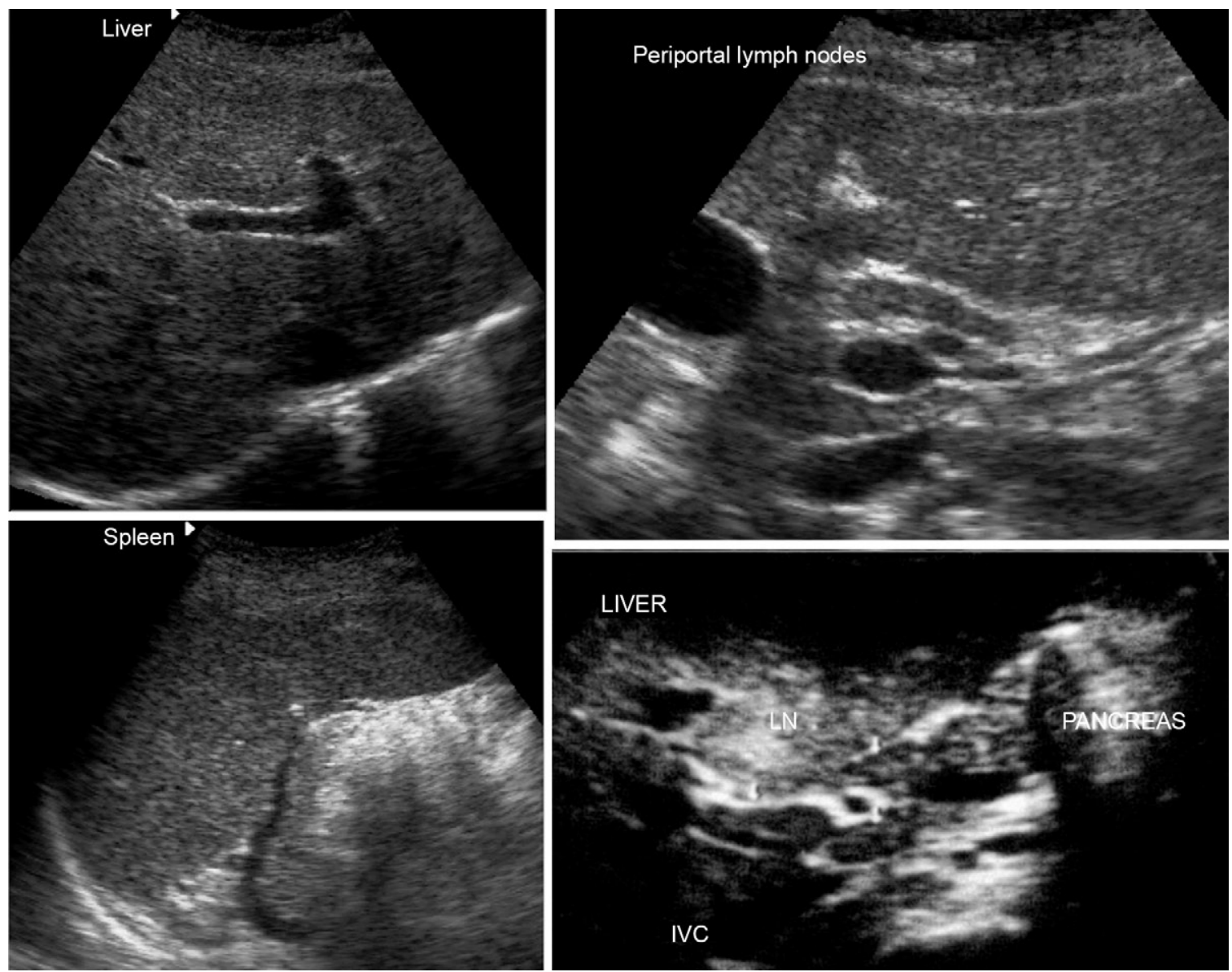

Fig. 2: sonographic features of acute schistosomiasis: non specific liver and spleen enlargement (left); enlarged periportal lymph nodes (right) with normal cortical hipoechogenicity surrounding a central echogenic hilum. IVC: inferior vena cava; LN: lymph node.

evolved. Our findings (Gerspacher-Lara et al. 1997) are similar to those of Homeida et al. 1988: patients with isolated central fibrosis did not present evidence of portal hypertension (splenomegaly and collateral vessels).

Other authors have emphasized the finding of periportal thickening in patients without eggs in stool, as well as the lower sensitivity of clinical examination in the evaluation of hepatomegaly and splenomegaly. Martins et al. (1998) reported that only $25 \%$ of patients with palpable spleens had periportal fibrosis. Marinho et al. (2006) observed that $23 \%$ of palpable spleens and $54 \%$ of palpable right liver lobes are shown by ultrasound to be of normal size. The liver consistency also had a weak correlation with periportal fibrosis. Portal hypertension may be seen without splenomegaly in cases with abundant hepatofugal collateral circulation or multiple splenic infarcts (haemolytic states). However, splenomegaly without periportal fibrosis may be seen in many clinical conditions, with or without liver disease.

A series of controversies in the use of ultrasound forced the WHO to convene a group of experts to create an ultrasound protocol (Hatz et al. 1992). The WHO sponsored the Cairo meeting (Cairo Working Group 1992) to conduct the first attempt of ultrasound standardization in schistosomiasis related morbidity. The conclusions of the Cairo Working Group were revised in the Second International Workshop in Niamey-Nigeria in 1996 (WHO 2000) and in the Satellite Symposium on Ultrasonography in Schistosomiasis in Belo Horizonte, Brazil in 1997 (Richter et al. 2001). As a result of the meetings, standard schematic plates (patterns) were developed, as shown in Fig. 3. The WHO patterns facilitated teaching for fieldbased ultrasound examinations; however, the inter-observer agreement remained low (King et al. 2003). In our opinion, previous ultrasound experience is important to increase consistency.

WHO patterns B, C, D and Dc, which represent patients with light liver fibrosis, are difficult to differentiate from normal liver and from other diseases (Ruiz-Guevara et al. 2007). In some cases, there is a tendency to overestimate the presence of schistosomal liver fibrosis.

Correlation with other imaging modalities - Lambertucci et al. (2004) and Silva et al. (2006) reported disagreements between ultrasound and MRI features in the evaluation of schistosomal liver involvement. Silva et al. (2006) found a moderate agreement between ultrasound and MRI in 60 patients with schistosomiasis mansoni. MRI was superior to ultrasound in the assessment of 


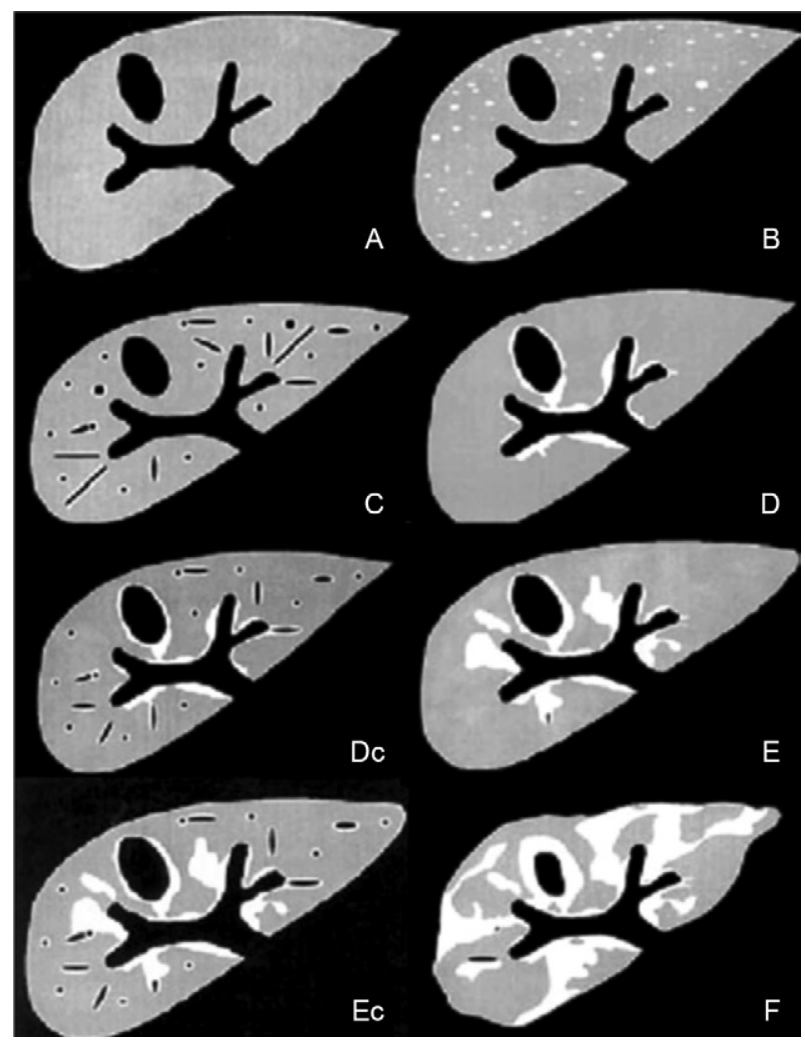

Fig. 3: sonographic standardization of the liver in schistosomiasis mansoni. A: normal; B: starry sky (peripheral fibrosis); C: rings and pipe-stems (initial fibrosis of segmentary branches); D: "ruff" around portal bifurcation, also known as central fibrosis; Dc: mixed form; E: patches, fibrosis around primary and segmentary portal branches; Ec: mixed form; F: bird claws, corresponding to marked central and peripheral fibrosis.

liver and spleen sizes, vascular dilation, collateral vessels and periportal thickening. The apparent gallbladder wall thickening described on ultrasound actually corresponds to adipose tissue infiltration.

MRI presented high inter-observer agreement. The field-of-view of the images includes the whole abdomen and the images can be saved for further review and analysis. Another study reported a poor agreement between ultrasound and MRI; the analysis of MRI showed perfect inter-observer agreement in 14 patients (Scortegagna et al. 2007).

Ultrasound is an effective and flexible diagnostic tool in the evaluation of a variety of diseases. It presents no harmful effects to patients, allowing non-invasive studies in hospitalized patients and in other facilities. Despite its limitations, which include its high dependence on operator skills, ultrasound may be used to measure intra-abdominal organs and vessels as well as to diagnose moderate to severe schistosomiasis and other liver diseases. Physical examination is more subjective and is especially difficult in obese and non-cooperative patients such as children. Data may be stored using the Digital Imaging and Communications in Medicine protocol and sent to other examiners via the internet. Portability and connectivity have also improved in new ultrasound devices.

\section{REFERENCES}

Abdel Wahab MF, el-Kady N, Arafa NM, Salama Z, Kotib AK, Nasef A, Abdou M, Hamam S, el-Din Hussein K 1979. Distal splenorenal shunts (Warren's operation) B-mode and real time ultrasonographic assessment. Egypt J Bilharz 6: 21-24.

Andrade ZA, Bina JC 1983. The pathology of the hepatosplenic form of schistosomiasis mansoni in its advanced form (study of 232 complete necropsies). Mem Inst Oswaldo Cruz 78: 285-305.

Andrade ZA, Cheever AW 1971. Alterations of the intrahepatic vasculature in hepatosplenic schistosomiasis mansoni. Am J Trop Med Hyg 20: 425-432.

Barata CH, Pinto-Silva RA, Lambertucci JR 1999. Abdominal ultrasound in acute schistosomiasis mansoni. Brit J Radiol 72: 949-952.

Bogliolo L 1957. Anatomical picture of the liver in hepato-splenic schistosomiasis mansoni. Ann Trop Med Parasitol 51: 1-14.

Cairo Working Group 1992. The use of diagnostic ultrasound in schistosomiasis - attempts at standardization of methodology. Acta Trop 51: 45-63.

Cerri GG, Alves VA, Magalhães A 1984. Hepatosplenic schistosomiasis mansoni: ultrasound manifestations. Radiology 153: 777-780.

Cesmeli E, Vogelaers D, Voet D, Duyck P, Peleman R, Kunnen M, Afschrift M 1997. Ultrasound and CT changes of liver parenchyma in acute schistosomiasis. Br J Radiol 70: 758-760.

Cota GF, Pinto-Silva RA, Antunes CM, Lambertucci JR 2006. U1trasound and clinical investigation of hepatosplenic schistosomiasis: evaluation of splenomegaly and liver fibrosis four years after mass chemotherapy with oxamniquine. Am J Trop Med Hyg 74: 103-107.

Coutinho AR 1964. Investigation of bilharziasis in a limited area of the district of Niassa. An Inst Med Trop (Lisb) 21: 321-335.

de Cleva R, Herman P, Saad WA, Pugliese V, Zilberstein B, Rodrigues JJ, Laudanna AA 2005. Postoperative portal vein thrombosis in patients with hepatosplenic mansonic schistosomiasis: relationship with intraoperative portal pressure and flow. A prospective study. Hepatogastroenterology 52: 1529-1533.

Doehring-Schwerdtfeger E, Mohamed-Ali G, Abdel-Rahim IM, Kardorff R, Franke D, Kaiser C, Elsheikh M, Ehrich JH 1989. Sonomorphological abnormalities in Sudanese children with Schistosoma mansoni infection: a proposed staging-system for field diagnosis of periportal fibrosis. Am J Trop Med Hyg 41: 63-69.

Domingues AL, Lima AR, Dias HS, Leao GC, Coutinho A 1993. An ultrasonographic study of liver fibrosis in patients infected with Schistosoma mansoni in North-east Brazil. Trans R Soc Trop Med Hyg 87: 555-558.

Fataar S, Bassiony H, Satyanath S, Vassileva J, Hanna RM 1984. Characteristic sonographic features of schistosomal periportal fibrosis. AJR Am J Roentgenol 143: 69-71.

Gerspacher-Lara R, Pinto-Silva RA, Rayes AAM, Drummond SC, Lambertucci JR 1997. Ultrasonography of periportal fibrosis in schistosomiasis mansoni in Brazil. Trans Roy Soc Trop Med Hyg 91: 307-309.

Hatz C, Jenkins JM, Morrow RH, Tanner M 1992. Ultrasound in schistosomiasis - a critical look at methodological issues and potential applications. Acta Trop 51: 89-97.

Homeida M, Abdel-Gadir AF, Cheever AW, Bennett JL, Arbab BM, Ibrahium SZ, Abdel-Salam IM, Dafalla AA, Nash TE 1988. Diagnosis of pathologically confirmed Symmers' periportal fibrosis by ultrasonography: a prospective blinded study. Am J Trop Med Hyg 38: 86-91.

Homeida MA, el Tom I, Nash T, Bennett JL 1991. Association of the 
therapeutic activity of praziquantel with the reversal of Symmers' fibrosis induced by Schistosoma mansoni. Am J Trop Med Hyg 45: 360-365.

Hussain S, Hawass ND, Zaidi AJ 1984. Ultrasonographic diagnosis of schistosomal periportal fibrosis. J Ultrasound Med 3: 449-452.

King CH, Magak P, Salam EA, Ouma JH, Kariuki HC, Blanton RE, World Health Organization 2003. Measuring morbidity in schistosomiasis mansoni: relationship between image pattern, portal vein diameter and portal branch thickness in large-scale surveys using new WHO coding guidelines for ultrasound in schistosomiasis. Trop Med Int Health 8: 109-117.

Lambertucci JR, Cota GF, Pinto-Silva RA, Serufo JC, GerspacherLara R, Drummond SC, Antunes CM, Nobre V, Rayes A 2001. Hepatosplenic schistosomiasis in field-based studies: a combined clinical and sonographic definition. Mem Inst Oswaldo Cruz 96 (Suppl.): 147-150.

Lambertucci JR, da Silva RA, Gerspacher-Lara R, Barata CH 1994. Acute Manson's schistosomiasis: sonographic features. Trans $R$ Soc Trop Med Hyg 88: 76-77.

Lambertucci JR, dos Santos Silva LC, Andrade LM, de Queiroz LC, Carvalho VT, Voieta I, Antunes CM 2008. Imaging techniques in the evaluation of morbidity in schistosomiasis mansoni. Acta Trop 108: 209-217.

Lambertucci JR, Rocha RS, Carvalho OS, Katz N 1987. A esquistossomose em Minas Gerais. Rev Soc Bras Med Trop 20: 47-52.

Lambertucci JR, Serufo JC, Gerspacher-Lara R, Rayes AA, Teixeira R, Nobre V, Antunes CM 2000. Schistosoma mansoni: assessment of morbidity before and after control. Acta Trop 77: 101-109.

Lambertucci JR, Silva LC, Andrade LM, de Queiroz LC, Pinto-Silva RA 2004. Magnetic resonance imaging and ultrasound in hepatosplenic schistosomiasis mansoni. Rev Soc Bras Med Trop 37: 333-337.

Marinho CC, Voieta I, Azeredo LM, Nishi MP, Batista TS, Pereira AC, Serufo JC, de Queiroz LC, Ruiz-Guevara R, Antunes CM, Prata A, Lambertucci JR 2006. Clinical versus ultrasound examination in the evaluation of hepatosplenic schistosomiasis mansoni in endemic areas. Mem Inst Oswaldo Cruz 101 (Suppl. I): 317-321.

Martins MJ, Pinto-Silva RA, Serufo JC, Rayes AAM, Damasceno MPS, Martins MLV, Santos APS, Drummond SC, Bezerra MAS, Lambertucci JR 1998. Morbidity of schistosomiasis in an endemic area of the northeast of the state of Minas Gerais in Brazil: a clinical and sonographic study. Mem Inst Oswaldo Cruz 93 (Suppl. I): 243-244.
Pinto-Silva RA, Abrantes WL, Antunes CM, Lambertucci JR 1994. Sonographic features of portal hypertension in schistosomiasis mansoni. Rev Inst Med Trop Sao Paulo 36: 355-361.

Rabello AL, Da Silva RA, Rocha RS, Katz N 1994. Abdominal ultrasonography in acute clinical schistosomiasis mansoni. Am J Trop Med Hyg 50: 748-752.

Richter J, Domingues AL, Barata CH, Prata AR, Lambertucci JR 2001. Report of the Second Satellite Symposium on Ultrasound in Schistosomiasis. Mem Inst Oswaldo Cruz 96 (Suppl.): 151-156.

Ruiz-Guevara R, de Noya BA, Valero SK, Lecuna P, Garassini M, Noya O 2007. Clinical and ultrasound findings before and after praziquantel treatment among Venezuelan schistosomiasis patients. Rev Soc Bras Med Trop 40: 505-511.

Santos GT, Sales DM, Leão ARS, Santos JEM, de Aguiar LAK, Brant PE, Shigueoka DC, Colleoni Neto R, D’Ippolito G 2007. Reprodutibilidade da classificação ultra-sonográfica de Niamey na avaliação da fibrose periportal na esquistossomose mansônica. Radiol Bras 40: 377-381.

Scortegagna Jr E, Leão ARS, Santos JEM, Sales DM, Shigueoka DC, Aguiar LAK, Brant PE, Colleoni Neto R, Borges DR, D'Ippolito G, Scortegagna Junior E, Leão ARS, Santos JEM, Sales DM, Shigueoka DC, de Aguiar LAK 2007. Avaliação da concordância entre ressonância magnética de ultra-sonografia na classificação de fibrose periportal em esquitossomóticos, segundo a classificação de Niamey. Radiol Bras 40: 303-308.

Silva LC, Pereira AC, Queiroz LC, Andrade LM, Antunes CM, Lambertucci JR 2006. Disagreement between ultrasound and magnetic resonance imaging in the identification of schistosomal periportal fibrosis. Mem Inst Oswaldo Cruz 101 (Suppl. I): 279-282.

Vezozzo DC, Farias AQ, Cerri GG, Da Silva LC, Carrilho FJ 2006. Assessment of portal hemodynamics by Doppler ultrasound and of liver morphology in the hepatosplenic and hepatointestinal forms of schistosomiasis mansoni. Dig Dis Sci 51: 1413-1419.

Widman A, de Oliveira IR, Speranzini MB, Cerri GG, Saad WA, Gama-Rodrigues J 2001. Hepatosplenic schistosomiasis portal hypertension: effect of esophagogastric devascularization with splenectomy on the diameter and mean flow velocity in the portal system (ultra-sonographic Doppler). Arq Gastroenterol 38: 19-23.

WHO - World Health Organization 2000. Second International Workshop 1996, Niamey. Ultrasound in schistosomiasis. A practical guide to the standardized use of ultrasonography for assessment of schistosomiasis-related morbidity, WHO, Geneva, 49 pp. 